\title{
IAMJ
}

INTERNATIONAL

AYURVEDIC

MEDICAL JOURNAL

ISSN: 2320-5091

Impact Factor: 6.719

\section{A CLINICAL STUDY OF DEVDALI HIMA NASYA AND DRONPUSHPI SWARASA ANJANA IN KAMALA (JAUNDICE)}

\author{
Rekha Kanwar $^{1}$, Mahesh Kumar Sharma², Gyan Prakash Sharma ${ }^{3}$ \\ ${ }^{1}$ P.G. Scholar, PG Department of Panchkarma, \\ ${ }^{2}$ M.D. (Ayu). Professor \& Head of Panchkarma Department \\ ${ }^{3}$ M.D. (Panchkarma) Associate Professor of Panchkarma Department \\ Dr. S.R. Rajasthan Ayurved University Jodhpur, Rajasthan, India
}

Corresponding Author: rekhashekhawat58@gmail.com

\section{https://doi.org/10.46607/iamj1309092021}

(Published Online: September 2021)

Open Access

(C) International Ayurvedic Medical Journal, India 2021

Article Received: 30/08//2021 - Peer Reviewed: 06/09/2021 - Accepted for Publication: 07/09/2021

\section{Check for updates}

\section{ABSTRACT}

Most people have become used to spicy fast-food day by day. This has taken human beings far away from nature. Nowadays alcohol consumption is also increasing day by day. Ayurvedic texts have mentioned hepatocellular jaundice as Kamala. Due to frequent intake of Pittakara Aahara (spicy and hot food), it leads to vitiation of Pitta Dosha and Virechana ${ }^{l}$ (purgation) is the first line of treatment for Pittadushti. Ayurvedic line of management According to lolimbraj (Vaidya jivana ${ }^{2}$ i.e., Nasya therapy and According to Chakradatta Anjana ${ }^{3}$ therapy in addition with above mentioned take 3 gm Triphala Churna with Lukewarm water at bedtime for Koshta shuddhi. Nasya and Anjana both are successful in Kamala by removing toxic waste from the body, and by correcting Agni (digestive fire). In our ancient classics, single drugs along with compound drugs have been mentioned in Kamala. These drugs have Kamalahara properties. This results in better circulation and nourishment of the organs and the diseases will subside. Kamala is a disease caused by an overabundance of Mala Ranjak Pitta. Nasya cleanses and energies the tissues and organs of the head and neck. Shodhan Nasya is a form of Nasya that promotes secretions and removes toxins from the body. Devadali Phal Nasya is a form of Shodhan, particularly Rechna Nasya, that causes accumulated Mala Ranjak Pitta to be excreted through the nose. Nasya is referred to as "Nastah Pracchardan" by Charaka ${ }^{4}$. It means Nasya is shodhan karma, which explains Nasya's position at the systemic level and why sr. bilirubin levels fall. Dronpushpi is Doşakarma Kaphavātaśamaka, Pittasamśodhaka Property.It is having 
Katu, Lavan,a, Madhura Rasa. It is laxative, angmintic, stimulant and febrifuge. The swarasa of this herb is applied as a collyrium (natrănjana) in case of jaundice.

Keywords: Jaundice, Kamala, Pitta Dushti, Nasya, Anjana, LFT.

\section{INTRODUCTION}

Kamala Roga is one of the common disorders of a hepatobiliary system which is mainly represented as the main clinical sign/symptom of liver disorders. It is nicely described in ancient classical Ayurvedic texts i.e., Bruhattryi, Laghuttrayi and other books of a late period. It is mentioned as an independent clinical entity as well as a complication of Pandu roga $a^{5}$. The disease is clinically represented by yellow discolouration (like the colour of rhizome of Haridra (Curcuma longa) of eyes, skin nails, mouth and urine and stool as a chief sign/symptom, suppressed function of sensory organs, Indigestion, and some generalized feature like burning sensation in whole body and weakness etc. Kamala is a pure Paittika disease that results from excessive use of Paittika Ahara and vihara (Pitta dosha vitiating diets and lifestyle) by the patient of Pandu Roga. According to Acharya Charaka ${ }^{6}$. Jaundice is a term used in modern medicine to describe a related health disorder. Since jaundice may be caused by a variety of osteopathological disorders that affect the liver and hepatobiliary system. Jaundice can be caused by a variety of factors, including diseases, drug poisoning, and alcoholism. It is now a raging clinical crisis in our everyday practice, impacting a sizable portion of society. However, there is no clear treatment for this clinicopathological agent available in modern medicine. Preventative steps are still recommended. It is either self-contained or resulted. In the absence of successful treatment, the patient's condition can often be fatal. In today's world, immunization procedures are widely used as a form of prevention for viral hepatitis, which is one of the most common causes of jaundice. Several herbal and Herbo-mineral drugs are listed in Ayurveda for the treatment of Kamala Roga (Jaundice). These have been used widely and effectively by Ayurveda physicians since ancient times. Some clinical research works have also been conducted from time to time by prestigious Ayurvedic educational and research institutes and bodies in the country, providing scientific evidence towards the efficacy of these drugs without any apparent side/ adverse effects, suggesting that these drugs are safe and harmless. Samshodhana therapy / Panchakarma (purificatory therapeutic procedures) are considered as the best for the treatment of diseases in Ayurveda as it cures the diseases with their root cause. NASYA Karma is one of the panchakarma procedures. Moreover, Chaksu (eyes) are the sthana (location) of Alochaka pitta, which is one of the five types of pitta, Anjana helps in the elimination of Dushita pitta from the eyes.

\section{Aim and Objectives: -}

Present clinical work has been undertaken with the following three main objectives:

(1) To study the comparative clinical effectiveness of Nasya and Anjana in patients of Kamala Roga.

(2) To study conceptually Kamala Roga vis-à-vis jaundice given Ayurveda and modern medicine.

(3) To evaluate the comparative clinical efficacy of Nasya and Anjana in Kamala Roga.

\section{Material and Methods: -}

Selection of cases: - The study will be conducted on 30 clinically diagnosed and confirmed cases of $\mathrm{Ka}$ mala from an associated group of the hospital of $\mathrm{Dr}$ S.R. Rajasthan Ayurveda University Jodhpur.

Grouping of Patients: - After Complete examination and investigation.30 patients will be divided randomly into two groups (15 Patients in each group) irrespective of their sex, religion, occupation, and age group in between 16-60 years.

Group A: Devdali Phala Hima Nasya, was given in the dose of 8 drops in each nostril of Devadali Phala Heem. 1, 2 times in a week for 1 month.

Group B: Dronpushpi Sawarasa Anjana, was given in the dose of $2 M L$ in eyes. i.e., $1 \mathrm{ML}$ for each eye. 1 ML equals 8 drops of Dronpushpi Sawarasa. 2-2 
drops of Dronpushpi Swarasa in morning total of 8 drops with a gap of 45 seconds between two dosages will be dropped in patients each eye once in a week for 1 month.

\section{Inclusion criteria:}

1. Patients between the ages of 15 to 60 years.

2. Normal patient of Kamala roga [jaundice] with no serious/ life-threatening complication.

\section{Exclusion criteria:}

[1] Age $<15$ and $>60$ years.

[2] Acute or chronic diarrhoea disorder.
[3] Bleeding, piles, prolapse of rectum and other anorectal surgical conditions.

[4] Serious infections like typhoid, tuberculosis

[5] Malignancy

[6] Excessive weak, and dehydrated condition.

[7] Metabolic disorders like diabetes mellitus, thyroid dysfunction etc.

[8] Serious cardiovascular disorders.

[9] Cirrhosis with portal hypertension.

[10] Peptic ulcer.

[11] Any other conditions in which Nasya and Anjan are contraindicated.

\section{Assessment Criteria: -}

Table 1: Subjective Parameters

\begin{tabular}{|c|c|c|c|c|c|}
\hline Lakshana & $\begin{array}{l}\text { Grade } \\
0\end{array}$ & Grade 1 & Grade 2 & Grade 3 & Grade 4 \\
\hline $\begin{array}{l}\text { 1.Haridra netra, } \\
\text { Twak, Nakha, } \\
\text { Anana }\end{array}$ & normal & mild & Moderate & Marked colour & Extremely \\
\hline $\begin{array}{l}\text { 2. Rakta Pita } \\
\text { Shakrit and } \mathrm{Mu}- \\
\text { tra }\end{array}$ & normal & mild & Moderate & very dark yellow colour & $\begin{array}{l}\text { reddish yellow } \\
\text { colour }\end{array}$ \\
\hline 3. Sveta varchasa & Absent & $\begin{array}{l}\text { light yellow col- } \\
\text { our }\end{array}$ & $\begin{array}{l}\text { Whitish } \\
\text { colour mixed with } \\
\text { a yellow tinge }\end{array}$ & intermittent clay colour & clay colour \\
\hline 4. jwara & normal & $\begin{array}{l}\text { the occasional } \\
\text { feeling of fever }\end{array}$ & $\begin{array}{l}\text { Rise in temperature } \\
\text { at least once a day. }\end{array}$ & $\begin{array}{l}\text { temperature from } 99 \mathrm{f} \text { to } \\
100 \mathrm{f} \text { with the frequency of } \\
3 \text { to } 5 \text { times a week }\end{array}$ & $\begin{array}{l}\text { continuous low } \\
\text { grade or high- } \\
\text { grade fever }\end{array}$ \\
\hline 5. vistambha & normal & $\begin{array}{l}\text { Constipation } 1 \text { to } \\
2 \text { times a week }\end{array}$ & $\begin{array}{l}\text { Constipation } 3 \text { to } 5 \\
\text { times a week }\end{array}$ & Continuous constipation & $\begin{array}{l}\text { Impacted faecal } \\
\text { matter in the colon }\end{array}$ \\
\hline 6. Daurbalya & Normal & mild & Moderate & Severe & $\begin{array}{l}\text { Unable to do any } \\
\text { work }\end{array}$ \\
\hline 7. Atopa & Absent & $\begin{array}{l}\text { The occasional } \\
\text { feeling of flatu- } \\
\text { lence }\end{array}$ & $\begin{array}{l}\text { Flatulence after } \\
\text { intake of a heavy } \\
\text { meal }\end{array}$ & $\begin{array}{l}\text { Flatulence after intake of a } \\
\text { light meal }\end{array}$ & Severe flatulence \\
\hline
\end{tabular}

\section{Objective Criteria: -}

1) $\mathrm{Hb} \%$

2)Total Bilirubin

3)Direct Bilirubin

4) In Direct Bilirubin

5)SGPT

6)SGOT 
Table 2: Over All Effect of Therapies: -

\begin{tabular}{|l|l|}
\hline Cured & $100 \%$ relief in signs and symptoms \\
\hline Marked improvement & $>75 \%$ relief in signs and symptoms \\
\hline Moderate improvements & 51 to $75 \%$ relief in signs and symptoms \\
\hline Mild improvement & 25 to $50 \%$ relief in signs and symptoms \\
\hline No Improvement & Below $25 \%$ \\
\hline
\end{tabular}

\section{Plan of Treatment:}

1. Devdali Phala Hima Nasya, was given in the dose of 8 drops $^{7}$ in each nostril of Devadali Phala Heem. 1, 2 times in a week for 1 month.

\section{Preparation of medicine: -}

Took five fruits of the Devdali, removed the prickly skins from them and pulled things out from inside. There was a web over these things, to remove them, put them in 6 Masha $(6 \mathrm{ml})$ of water and put them in a small glass vessel. Again after 1 to 2 hours, mash it well and throw the web. Then filter that water and put it in a vial. First licked some accumulated ghee, that put 8 drops of rasa in the nostril and asked to pull it up. Then in the other nostril, in the same way, the Nasya was given. After doing this, mucus started falling from the nose in a short time. Let it fall for two pranhara. By doing this a lot of yellow water will fall and jaundice will reduce and disappear.

2. Dronpushpi Sawarasa Anjana, was given in the dose of $2 \mathrm{ML}$ in eyes. i.e., $1 \mathrm{ML}$ for each eye. $1 \mathrm{ML}$ equals 8 drops of Dronpushpi Sawarasa. 2-2 drops of Dronpushpi swarasa in morning total of 8 drops with a gap of 45 seconds between two dosages will be dropped in patients each eye once in a week for 1 month.

\section{Preparation of medicine: -}

Fresh Leaves of Dronpushpi was made into bolus and swarasa was extracted and used for anjana in a dose of 2ML. Dronpushpi Swarasa was applied in both eyes gently i.e., $1 \mathrm{ML}$ for each eye. $1 \mathrm{ML}$ equals 8 drops of Dronpushpi Sawarasa.

Observation: - In the Case of demographic data, most patients i.e. The highest was seen in the age group of 31-45 yrs., Male, Middle class. Most of the patients i.e., 50\% were having Vata-Pittaja Sharirika Prakriti and $46.66 \%$ were having mandagni, 60\% were having krura Koshtha. $60 \%$ of patients were addicted to alcohol, tea.

$36.67 \%$ of patients were having Madhyama saara, $53.33 \% \%$ patients were found to have Madhyama Samhanana, 60\% were having Madhyama Satva, 73.33\%) were having Madhyama Satmya, 46.67\% were having Madhyama Vyayama Shakti, $63.27 \%$ were having Avara Abhyav Aharana Shakti, $40.00 \%$ had Madhyama Nidra Pravarti.

No side effect was reported by any of the patients during therapy. All the patients tolerated the panchakarma procedure very well.

\section{Results: -}

Intra Group comparison of subjective parameter:

Table 3: Showing the effect of therapy in Subjective Parameters (Wilcoxon Matched pairs Signed Ranks Test)

\begin{tabular}{|c|c|c|c|c|c|c|c|c|c|}
\hline \multirow{2}{*}{$\begin{array}{l}\text { Sign \& Symp- } \\
\text { toms }\end{array}$} & \multirow[t]{2}{*}{ Gr. } & \multicolumn{2}{|c|}{ Mean score } & \multirow[t]{2}{*}{ Difference } & \multirow{2}{*}{$\begin{array}{l}\% \\
\text { Relief }\end{array}$} & \multirow[t]{2}{*}{ S.D \pm} & \multirow[t]{2}{*}{ S.E \pm} & \multirow[t]{2}{*}{ P-value } & \multirow[t]{2}{*}{ Result } \\
\hline & & BT & AT & & & & & & \\
\hline \multirow{2}{*}{$\begin{array}{l}\text { Haridra netra, } \\
\text { Twak, Nakha, } \\
\text { Anana }\end{array}$} & $\mathbf{A}$ & 2.786 & 0.7857 & 2.000 & $73.17 \%$ & 0.3922 & 0.1048 & $<0.0001$ & E.S. \\
\hline & B & 2.500 & 0.7857 & 1.714 & $67.57 \%$ & 0.4688 & 0.1253 & $<0.0001$ & E.S. \\
\hline \multirow{2}{*}{$\begin{array}{ll}\text { Rakta } & \text { Pita } \\
\text { Shakrit } & \text { and } \\
\text { Mutra } & \end{array}$} & A & 1.200 & 0.3333 & 0.8667 & $72.22 \%$ & 0.9155 & 0.2364 & $<0.0039$ & V.S. \\
\hline & B & 1.400 & 0.5333 & 0.8667 & $61.90 \%$ & 0.8338 & 0.2153 & $<0.0020$ & V.S. \\
\hline \multirow[t]{2}{*}{ Sveta varchasa } & $\mathbf{A}$ & 1.133 & 0.4667 & 0.6667 & $58.82 \%$ & 0.8165 & 0.2108 & $<0.0078$ & V.S. \\
\hline & B & 0.8000 & 0.3333 & 0.4667 & $58.83 \%$ & 0.6399 & 0.1652 & $<0.0156$ & S. \\
\hline
\end{tabular}




\begin{tabular}{|l|l|l|l|l|l|l|l|l|l|}
\hline \multirow{3}{*}{ Jwara } & $\mathbf{A}$ & 1.333 & 0.5333 & 0.8000 & $60.00 \%$ & 0.7746 & 0.2000 & $<0.0020$ & V.S. \\
\cline { 2 - 10 } & $\mathbf{B}$ & 1.200 & 0.5333 & 0.6667 & $55.56 \%$ & 0.6172 & 0.1594 & $<0.0020$ & V.S. \\
\hline \multirow{2}{*}{ vistambha } & $\mathbf{A}$ & 2.133 & 0.6000 & 1.533 & $71.88 \%$ & 0.6399 & 0.1652 & $<0.0001$ & E.S. \\
\cline { 2 - 10 } & $\mathbf{B}$ & 1.867 & 0.6000 & 1.267 & $67.86 \%$ & 0.7037 & 0.1817 & $<0.0001$ & E.S \\
\hline \multirow{2}{*}{ Daurbalya } & $\mathbf{A}$ & 2.467 & 0.7333 & 1.733 & $70.27 \%$ & 0.4577 & 0.1182 & $<0.0001$ & E.S \\
\cline { 2 - 10 } & $\mathbf{B}$ & 2.200 & 0.8000 & 1.400 & $63.64 \%$ & 0.6325 & 0.1633 & $<0.0001$ & E.S \\
\hline \multirow{2}{*}{ Atopa } & $\mathbf{A}$ & 2.733 & 0.9333 & 1.800 & $65.85 \%$ & 0.5606 & 0.1447 & $<0.0001$ & E.S \\
& $\mathbf{B}$ & 2.333 & 1.067 & 1.267 & $54.29 \%$ & 0.8837 & 0.2282 & $<0.0002$ & E.S \\
\hline
\end{tabular}

Table 4: Showing the effect of therapy in Objective Parameters (Paired 'T' Test)

\begin{tabular}{|c|c|c|c|c|c|c|c|c|c|c|}
\hline & \multirow[t]{2}{*}{ Gr. } & \multicolumn{2}{|c|}{ Mean score } & \multirow[t]{2}{*}{ Difference } & \multirow{2}{*}{$\begin{array}{l}\% \\
\text { Relief }\end{array}$} & \multirow[t]{2}{*}{ S.D \pm} & \multirow[t]{2}{*}{ S.E \pm} & \multirow[t]{2}{*}{ P-value } & \multirow{2}{*}{$\begin{array}{l}\text { t } \\
\text { value }\end{array}$} & \multirow[t]{2}{*}{$\mathbf{S}$} \\
\hline & & BT & AT & & & & & & & \\
\hline \multirow{2}{*}{$\begin{array}{l}\text { Total } \\
\text { Bilirubin }\end{array}$} & $\mathbf{A}$ & 5.987 & 3.187 & 2.800 & $46.77 \%$ & 0.9381 & 0.2422 & $<0.0001$ & 11.560 & E.S \\
\hline & B & 6.267 & 4.113 & 2.153 & $34.36 \%$ & 0.9039 & 0.2334 & $<0.0001$ & 9.227 & E.S \\
\hline \multirow{2}{*}{$\begin{array}{l}\text { Direct } \\
\text { Bilirubin }\end{array}$} & $\mathbf{A}$ & 3.353 & 1.687 & 1.667 & $49.70 \%$ & 0.3976 & 0.1027 & $<0.0001$ & 16.234 & E.S \\
\hline & B & 3.280 & 1.927 & 1.353 & $41.26 \%$ & 0.8070 & 0.2084 & $<0.0001$ & 6.495 & E.S \\
\hline \multirow{2}{*}{$\begin{array}{l}\text { Indirect } \\
\text { Bilirubin }\end{array}$} & $\mathbf{A}$ & 3.287 & 1.693 & 1.593 & $48.48 \%$ & 1.091 & 0.2817 & $<0.0001$ & 5.655 & E.S \\
\hline & B & 3.773 & 2.233 & 1.540 & $40.81 \%$ & 0.7962 & 0.2056 & $<0.0001$ & 7.491 & E.S \\
\hline \multirow[t]{2}{*}{ SGOT } & $\mathbf{A}$ & 176.67 & 97.667 & 79.000 & $44.72 \%$ & 46.721 & 12.063 & $<0.0001$ & 6.549 & E.S \\
\hline & B & 133.47 & 90.133 & 43.333 & $32.47 \%$ & 18.465 & 4.768 & $<0.0001$ & 9.089 & E.S \\
\hline \multirow[t]{2}{*}{ SGPT } & $\mathbf{A}$ & 194.80 & 97.867 & 96.933 & $49.76 \%$ & 69.301 & 17.893 & $<0.0001$ & 5.417 & E.S \\
\hline & B & 125.59 & 73.953 & 51.640 & $41.12 \%$ & 38.002 & 9.812 & $<0.0001$ & 5.263 & E.S \\
\hline
\end{tabular}

\section{INTERGROUP COMPARISON OF EFFECT OF THERAPIES}

Table 5: Showing Inter Group comparison in Subjective Parameters:(Mann-Whitney test)

\begin{tabular}{|l|l|l|l|l|l|l|}
\hline S.no & Subjective parameter & Mean diff. Group A & Mean diff. Group B & MW-U & P-Value & Result \\
\hline 1. & Haridra netra, Twak, Nakha, Anana & 2.000 & 1.714 & 77.50 & 0.0260 & S \\
\hline 2. & Rakta Pita Shakrit and Mutra & 0.8667 & 0.8667 & 73.50 & 0.4912 & NS \\
\hline 3. & Sveta varchasa & 0.6667 & 0.4667 & 80 & 0.2798 & NS \\
\hline 4. & Jwara & 0.4667 & 0.6667 & 103 & 0.3496 & NS \\
\hline 5. & vistambha & 1.533 & 1.267 & 88.50 & 0.1396 & NS \\
\hline 6. & Daurbalya & 1.733 & 1.400 & 73.50 & 0.0290 & S \\
\hline 7. & Atopa & 1.800 & 1.267 & 71.50 & 0 & S \\
\hline
\end{tabular}

\section{INTERGROUP COMPARISON OF OBJECTIVE PARAMETER: -}

Table 6: Showing Inter Group comparison in Objective Parameters (Unpaired t-Test)

\begin{tabular}{|l|l|l|l|l|l|}
\hline Objective Parameter & Mean diff. Group A & Mean diff. Group B & T value & P-value & Result \\
\hline Total Bilirubin & 2.800 & 2.153 & 1.923 & 0.0324 & $\underline{\mathrm{S}}$ \\
\hline Direct Bilirubin & 1.667 & 1.353 & 1.349 & 0.0941 & $\underline{\mathrm{NS}}$ \\
\hline Indirect Bilirubin & 1.593 & 1.540 & 0.1529 & 0.4398 & $\underline{\mathrm{NS}}$ \\
\hline SGOT & 79.000 & 43.333 & 2.750 & 0.0052 & $\underline{\text { V.S }}$ \\
\hline SGPT & 96.933 & 51.640 & 2.219 & 0.0174 & $\underline{\mathrm{S}}$ \\
\hline
\end{tabular}


Table 7: Total Effect of Therapy in the Patients of Kamala (Jaundice)

\begin{tabular}{|l|l|l|l|l|}
\hline & GROUP A (15 Patients) & $\mathbf{\%}$ & GROUP B (15 Patients) & \% \\
\hline Cured & 0 & $0 \%$ & 0 & $0 \%$ \\
\hline Marked improvement & 8 & $53.33 \%$ & 4 & $26.67 \%$ \\
\hline Moderate improvement & 7 & $46.67 \%$ & 10 & $66.67 \%$ \\
\hline Mild improvement & 0 & $0 \%$ & 1 & $6.66 \%$ \\
\hline No Improvement & 0 & $0 \%$ & 0 & $0 \%$ \\
\hline
\end{tabular}

Graph 1: Showing the Effect of therapy on Subjective Parameter in Group A

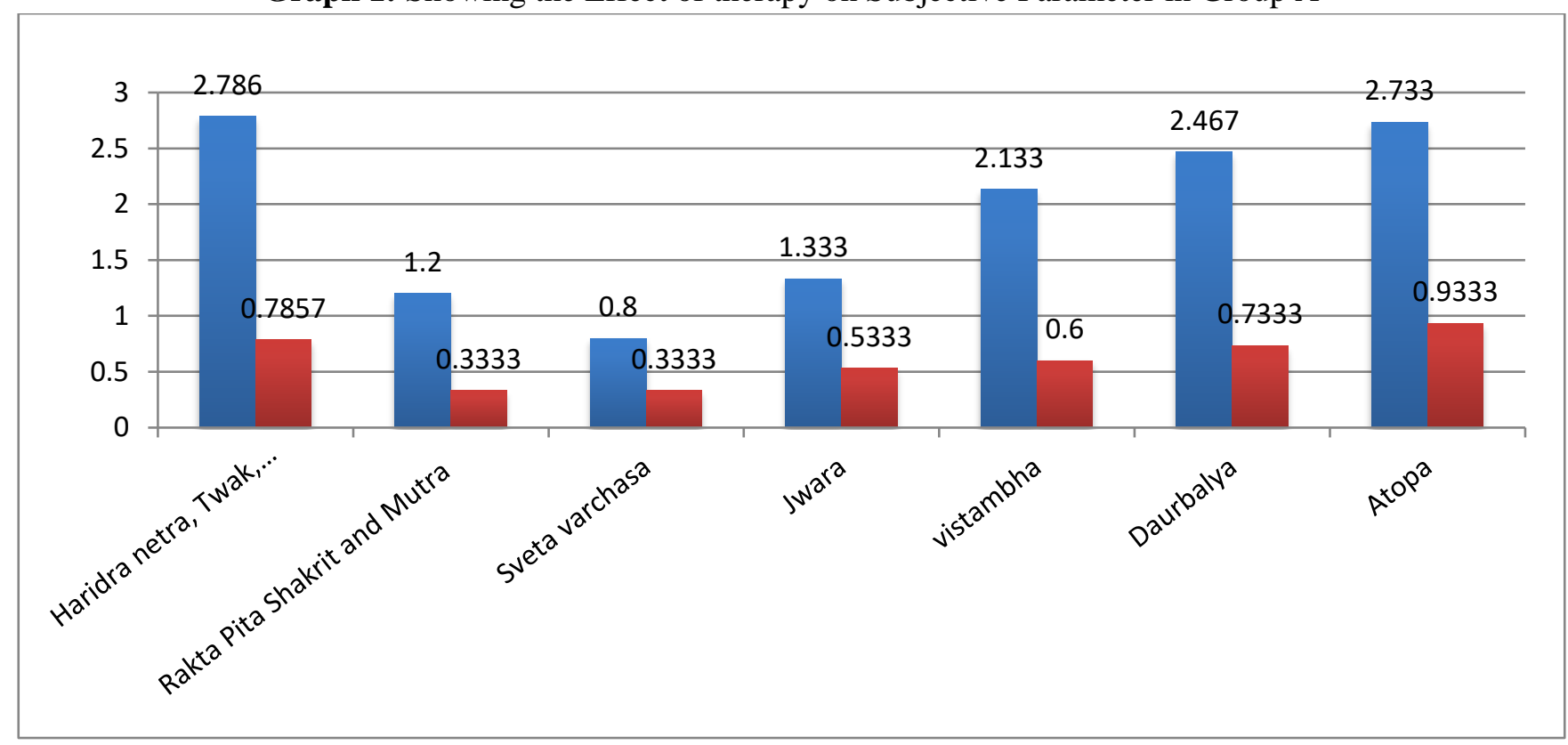

Graph 2: Showing the Effect of therapy on Subjective Parameter in Group B

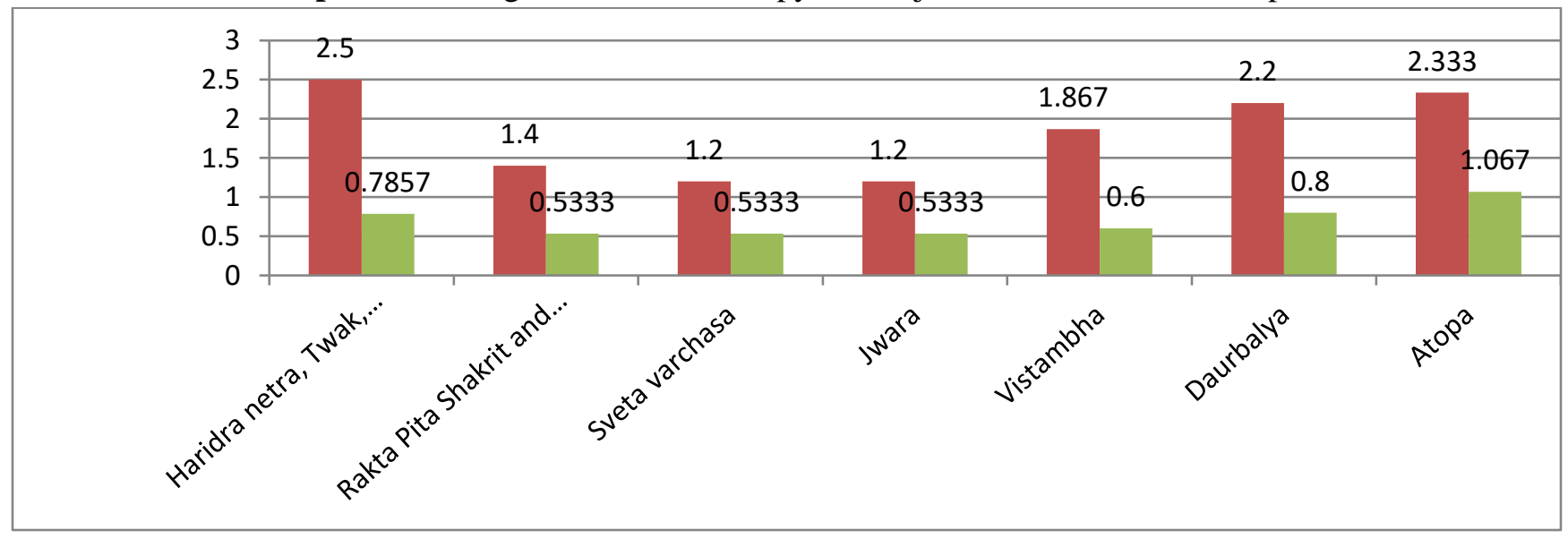

\section{DISCUSSION}

Asatmya Ahara Sevana, excessive intake of Amla, Lavana, Katu and Madhura Rasa Pradhan Ahara Dravya, Ruksha, Guru, Sheeta Guna Ahara padarthas vitiates the Jatharagni, the hypo functioning of
Jatharagni leads to the Kamala. Excessive vyayama leads to Pitta and Vata Dosha prakopa takes place further it leads to Dhatukshaya, simultaneously impaired the Kayaagni. Excessive day sleep aggravates the Vata and Kapha, which leads to Agnimandya. The 
natural urges like Mala, Mootra forcefully control, aggravates Vata Dosha, vitiated Vata cause Kayaagni vikruti, and leads to Mandagni.

Manasika Karanas like stress and strain are observed in the present study. So, it was concluded that there is no role in the Kamala. The specific Samprapti of Kamala is not mentioned in the classics. Only Shakhashrita Kamala Nidana and Samprapti explained from the above etiological factors one can establish the process of pathogenesis as under Pandu Roga in these conditions, the patient not taken proper medication and indulgence of an excessive amount of Pitta Vardhaka Aharas are vitiate the Pitta. Daha, Pachana, Virechan Karma unbalancing and not proper nourishing the Rasa, Raktadi Dhatu. In Shakhashrita Kamala excessive intake of Guru, Sheeta, Rooksa, Madura Rasa Ahara, aggravates the Kapha Vata Dosha and diminishes the Pitta. Increased Kapha in the Pitta Marga resulting on Vimarga gamana of Pitta, this results in the Shakhashrita Kamala.

\section{Mode of action of the therapy: -}

Nasya: Nasya Dravya (medicine) works by touching 'Sringataka Marma' (a key vital point on the surface of the brain corresponding to the nerve centres, which are made up of nerve cells and fibres that control speech-Centre, Broca's vision, hearing, taste, and smell). It extends into different Strotasa (vessels and nerves) and causes the bread to become vitiated.

The Sringataka is a composite structure made up of four siras (arteries) that link the nose, ear, eye, and tongue. Sringataka is the name given to the composite structure created when these four arteries are joined together. The vitiated Doshas should be brought to the site from their original seat, according to the ayurvedic school of thought. This movement will occur through the Srotasa (channels), and any disruption in the integrity of the srotas will result in disease growth. There should be some disruption in the usual functions of Urdwanga Srotasa when it comes to Urdhwanga Rogas (head diseases) (arteries, veins, nerves in the head). Sringataka is the most important Srotas in the Urdhwanga (head), and drugs that pass through these Srotasa are guaranteed to cause Srotosuddhi (cleansing) in Urdhwanga.

Kamala is a disease caused by an overabundance of Mala Ranjak Pitta. Nasya cleanses and energies the tissues and organs of the head and neck. Shodhan Nasya is a form of Nasya that promotes secretions and removes toxins from the body. Devdali Phal Nasya is a form of Shodhan, particularly Rechna Nasya, that causes accumulated Mala Ranjak Pitta to be excreted through the nose. Nasya is referred to as "Nastah Pracchardan" by Charaka. It means Nasya is shodhan karma, which explains Nasya's position at the systemic level and why sr. bilirubin levels fall. Medication administered through the nose assists in the correction of Prana disorders that affect higher cerebral, visual, and motor functions. The mechanism of Nasya can be summarized in one phrase from the ayurvedic classics: "Nasahi Shirasodwaram," i.e., the nose is a pharmacological passage through the brain.

\section{The action of drugs used in Nasyakarma:}

It is irritant to sensory organs, stimulates watery discharge \& used as purifying measure.

1). It is having Katu, Tikta Rasa, Kapha Pittahara \& Tridoshahar property.

2). Nasya was given in a dose of 8 drops in each nostril of Devadali Phala Heema.

3 ). This results in better circulation and nourishment of the organs and the diseases will subside.

The drug DEVDALI described for Nasya therapy have got Katu (bitter), Ushna (hot) and Theekshna (sharpness) properties. These drugs produce Draveekaranam (liquefaction) and Chedhana (expulsion) of vitiated Doshas ${ }^{7}$.

Devadali Nasya causes excretion of accumulated toxins in the body by lowering Sr. Bilirubin, Sr. Alk. Phos. alt, ast. Bile salts and bile pigments are present in nasal secretions. In Kothashakhashrita Kamala, Devadali Nasya is extremely beneficial. It is more helpful in the case of Kamala's recent onset. Finally, the nose can be said to be the gateway to the brain as well as the gateway to consciousness. Breathing in through the nose allows prana, or life force, to penetrate the body.

Anjana:- Once applied an Anjana it acts as a foreign body to the ocular surface. Hence eye gets reflex se- 
cretion in response to foreign particles on the cornea and conjunctiva. Due to that considerable amount of drug washes out from the eye by weeping and another major portion may drainage to the nasolacrimal duct (NLD). Apart from these another part may be eliminated from the ocular surface by evaporation (mainly Rasakriya Anjana), metabolization by tear enzymes and get in contact with tear proteins.

Finally, its mains in the cul-de-sac a very less amount of Anjana for the ocular absorption; meanwhile the portion drainage to the NLD may absorb to the systemic circulation by nasal-laryngeal and oral mucosa. On the other hand, Gutika and Churna Anjana have microparticles that may be deposited in the cul-de-sac and thereby increase the bioavailability to enhance ocular absorption.

The ocular absorption of Anjana may initiate through the conjunctiva and cornea. Mainly lipophilic active ingredients may absorb through the cornea by transcellular pathway and hydrophilic from the conjunctiva by paracellular pathway. This ocular absorption may be dependent on passive diffusion, carriermediated transport (facilitated diffusion and active transport) and endocytosis. Also, $\mathrm{pH}$, viscosity, tonicity and most importantly molecular size and molecular weight of the active ingredients play a major role in the same. Once it crosses the conjunctiva (mainly hydrophilic); the sclera is more permeable and it allows drugs to penetrate the other interior structures of the eye i.e., ciliary body, iris, aqueous houmer, lens, vitreous etc. But due to the high vascularization of the conjunctiva, ciliary body and iris considerable amount of drug may be entered into the systemic circulation again.

The drugs pass through the corneal epithelium (mainly lipophilic) directly goes to the aqueous humour and distribute to the other ocular tissues. However, some of the drugs coming to the aqueous humour either via cornea or conjunctiva are undergoing metabolization by the enzymes present in the aqueous. Considering all these factors it can be said that Anja$n a$ therapy may be highly activated in the anterior segment of the eye because of the presence of several anatomical, biological, and physiological ocular bar- riers. But in the system of Ayurveda pharmacological actions of a drug may explain according to its pharmacological properties which are included Rasa, Guna, Virya, Vipaka and Prabhava. These qualitative qualities are still not explained and interpreted by modern science. Hence as per the view of Ayurveda, these qualitative measures may act on the posterior segment of the eye.

\section{The action of drug used in Anjana:-}

Doşakarma: Kaphavātaśamaka, Pittasamśodhaka Property. It is having Katu, Lavan,a, Madhura Rasa ${ }^{8}$. It is laxative, animistic, stimulant and febrifuge. The swarasa of this herb is applied as a collyrium (natrănjana) in case of jaundice. Anjana was given in the dose of 2ML in eyes of Dronpushpi Sawarasa, i.e., 1ML for each eye. 1 ML equals 8 drops of Dronpushpi Sawarasa. Ashchayotan Dharan kala is 100 Matra according to Sharangdhara ${ }^{9}$. And 100 Matra equals 3 mints.2-2 drops of Dronpushpi swarasa in morning total of 8 drops $^{10}$ with a gap of 45 seconds between two dosages will be dropped in patients each eye once in a week for 1 month. In addition, with above mentioned taking 3 gm Triphala Churna with Lukewarm water at bedtime for Koshta shuddhi. It has a good cholagogue action and is given in certain diseases of biliary affections.

\section{CONCLUSION}

Jaundice correlates with Swatantraja Kamala and Koshtashrita, Ruddhapatha Kamala and Kumbha Kamala are the stages of it. Mostly patient was chosen for treatment in the rainy season because that time mostly patient was suffering from jaundice due to Agnimandhya. Addicted (Alcoholic), middle-aged patients are more prone to Jaundice. In Acute cases, the normal range of SGOT \& SGPT was attained with 1 month, whereas in chronic cases it took 2-3 months. The overall response of the clinical study suggests that Devdali phal Nasya and Dronpushpi Sawarasa anjana is very effective in the reduction of serum bilirubin level in blood. The result was effective in group A because Devdali phal Nasya is irritant to sensory organs and stimulates watery discharge through nasa. Yellow colouration of eyes, skin, nails, 
face, urine symptoms are extremely reduced in group A because these symptoms were related to serum bilirubin level. During Nasya time reduction of serum bilirubin level was observed within 7 days.

\section{REFERENCES}

1. Pt. Kasinatha Sastri and Dr Gorakha Natha Chaturvedi, Charaka Samhita of Agnivesha, Chaukhambha Bharati Academy, Varanasi; Reprint Edition:2013, vol.1, chikitsa Sthana chapter 16.

2. Dr Brahmanand Tripathi, Lolimbraj granthavali, Chaukhambha Surbharti Prakashan, Varansi; Vimana sthana, Chapter 3.

3. Pandit Jagannathan Sharma, Khemraj shri Krishnadas prakashan, Mumbai. Edition 2006, chakardatt Chikitsa sthana Chapter 16, Shloka 25.

4. Pt. Kasinatha Sastri and Dr Gorakha Natha Chaturvedi, Charaka Samhita of Agnivesha, Chaukhambha Bharati Academy, Varanasi; Reprint Edition:2013, vol.1, Siddhi Sthana chapter 1

5. Kaviraj Ambikadatta Shastri Edited Susruta Samhita, Chaukhambha Sanskrit Sansthan, Varansi; Reprint Edition:2013, vol 1, Uttar tantra chapter 44.

6. Pt. Kasinatha Sastri and Dr Gorakha Natha Chaturvedi, Charaka Samhita of Agnivesha, Chaukhambha Bharati Academy, Varanasi; Reprint Edition:2013, vol.1, chikitsa Sthana chapter 16.

7. Raj Nighantu, Narhari Pandita, Aacharya Balakrishna, Divya Prakashna, Edition 2016

8. Kaiyadeva Nighantu, P.K Gode, Acharya Surendra Mohan first volume. Lahore 1928

9. Vaidya ratan Pandit Ram Prasad Raj Vaidya Patiyalakrata, Khemraj shri Krishnadas prakashan, Mumbai, Sharangdhara samhita Uttar khanda, Chapter 13, Shloka 15.

10. Vaidya ratan Pandit Ram Prasad Raj Vaidya Patiyalakrata, Khemraj shri Krishnadas prakashan, Mumbai, Sharangdhara samhita Uttar khanda, Chapter 13, Shloka17.

\section{Source of Support: Nil Conflict of Interest: None Declared}

How to cite this URL: Reßha Kanwar et al: A Clinical Study of Devdali Hima Nasya And Dronpushpi Swarasa Anjana In Kamala (Jaundice). International Ayurvedic Medical Journal \{online\} 2021 \{cited September 2021\} Available from: http://www.iamj.in/posts/images/upload/2012_2020.pdf 